\title{
OBSERVATIONS ON THE NIGHT TIDAL MIGRANT CRUSTACEA OF KAMES BAY
}

\author{
By E. Emrys Watkin, Ph.D., D.Sc. \\ From the Department of Zoology, University College of Wales, \\ Aberystwyth, and the Marine Biological Station, Millport
}

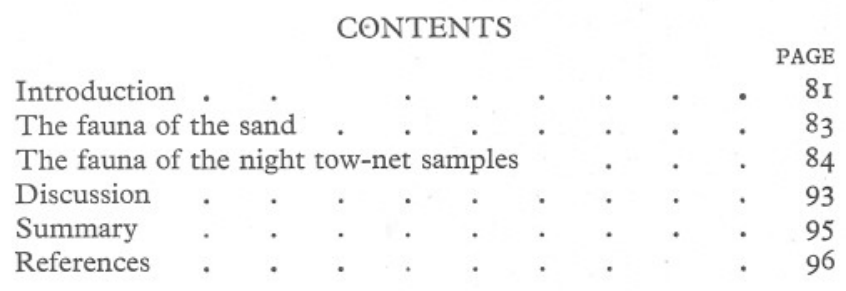

\section{INTRODUCTION}

During the year $1936 \mathrm{Mr}$ Richard Elmhirst, Director of the Scottish Marine Biological Station at Millport, carried out a series of night tow-nettings across the waters of Kames Bay* at varying times after nightfall, mainly between the hours of Io p.m. and midnight. The series was taken in order to ascertain the nature and extent of the faunal immigration into the bay from outside waters, and the nocturnal and vertical movement of the fauna which normally lies buried in the sand during the day. The net employed was an ordinary coarse tow-net supplemented on occasions by a finer net; the latter net, however, captured but few macro-Crustacea, and its results will be neglected in the present paper. The method employed was to walk into the water at the edge of the incoming or outflowing tide to a depth of about $2 \mathrm{ft}$. and to walk across the bay following the edge of the tide trailing the net about io $\mathrm{ft}$. posteriorly and at arm's length into the tidal flow, thus avoiding as far as possible disturbances set up in the water by the walking movement. The length of tow was approximately Ioo yards. Thus the position of each sample is determined by the time it was taken in relation to the day of the lunar month, and samples were obtained at all levels from high-water mark to lowwater mark. I have previously dealt with the species of the amphipod genus Bathyporeia which occurred in these samples (Watkin, 1939). In this paper the remainder of the macro-crustacean fauna apart from the mysids is analysed. I am indebted to $\mathrm{Mr}$ Elmhirst for handing over these samples to me for analysis, and for his critical comments during the investigation.

An appreciation of the fauna of the samples is amplified by a knowledge of the fauna which normally lives in the intertidal sand of the bay. This enables

* A map and a brief description of Kames Bay has been given in a previous paper (Watkin, I939, p. 470). 
the distinction to be drawn between those species which perform simple vertical migrations from the sand into the intertidal waters and those which are carried in by the tide into the intertidal area from the various habitats which lie beyond the low-water mark of spring tides. For this purpose a series of sand samples for faunal analysis was taken during the last week of March and the first week of April 1939. It is realized that a period of over two years separates the time when the tow-net samples were taken from that when the sand samples were obtained. It is known, however, that no major differences in the fauna occurred in the meantime, although differences in the density of a particular species may have occurred. The general conclusions are not invalidated by this time difference.

The method of faunal analysis of the sand was to fix stations, at 5-yard intervals, from the high-water mark to the low-water mark of spring tides along a sampling line previously used in the investigations of Elmhirst (I93I) and Stephen (I928 and subsequent dates) into the sand fauna of the bay. At each station a block of sand of I sq. ft. surface area and of a depth of 6 in. was removed and sieved through a brass wire sieve of 30 meshes to the linear inch. The detailed analysis of this series of samples will form the subject of a separate paper. For the purposes of this paper reference will be made only to the species which also occur in the night tow-net samples.

A comparison of the species which occur in the night tow-net samples with those of the sand samples shows that the night migrant fauna falls into two distinct groups.

(a) Those species which normally lie buried in the intertidal sand during the day and perform vertical movements only, retaining their zonation when swimming in the tidal waters. These are the amphipods Bathyporeia pilosa Lindström, B. pelagica (Bate), B. elegans Watkin and B. guilliamsoniana (Bate), Pontocrates norvegicus Boeck, P. arenarius (Bate) and Urothoë brevicornis Bate; the isopod Eurydice pulchra Leach; and the cumaceans Pseudocuma cercaria (van Beneden) and Cumopsis goodsiri (van Beneden). The above species represent the dominant forms that occur in the sand, apart from Haustorius arenarius (Slabber) which did not appear in the night tow-net samples. Apart from these an occasional specimen of Nototropis swammerdami (M.-Edw.), Megaluropus agilis Hoek, Lamprops fasciata Sars, Iphinoë trispinosa (Goodsir) and Crangon vulgaris Linn. also occurred in the sand samples.

(b) Those species that do not occur in the intertidal sand, but are carried in with the inflowing tide from various habitats beyond low-water mark and thus perform a horizontal, in addition to a vertical, migration. These habitats may be classified as (I) the sand habitats which extend outwards from lowwater mark to the deeper waters of the Firth of Clyde, and (2) the algal habitats. The latter harbour during the day species which cling to clumps of seaweed on the sea floor beyond the low-water mark of spring tides, and may also include the algal dwellers of the rock shore, which, until further evidence 
is available, may be expected to contribute to the night migrant population. The main species in the second group are the amphipods Gammarus locusta (Linn.), Nototropis swammerdami (M.-Edw.), Calliopius rathkei (Zaddach), Dexamine thea Boeck, and Apherusa spp.; the isopod Idotea viridis (Slabber) and the mysid Schistomysis spiritus Norman. Other species which occur only rarely in the samples are Marinogammarus spp., Megaluropus agilis Hoek, Stenothoë monoculoides (Montagu), Podoceros falcatus (Montagu), Metaphoxus fultoni (T. Scott), Periculodes longimanus (Bate \& Westw.), Erichthonius braziliensis (Dana), Siphonoecetes colleti Boeck, Phtisca marina Slabber, Hyale sp., Iphinoë trispinosa (Goodsir), Lamprops fasciata Sars, Diastylis rathkei (Kröyer) and Bodotria scorpioides (Montagu).

The rare appearance of such algal dwellers as Stenothoë, Podoceros and Phtisca is probably due to the drift of bits of algae, and of the tube dwellers such as Erichthonius and Siphonoecetes to storm action; they cannot at the moment be regarded as night migrants. The sand dwellers, such as Megaluropus, Periculodes, Metaphoxus and the cumaceans, may perform extensive vertical migrations over their respective habitats.

\section{The Fauna of The SAND}

The analysis of the crustacean population of the sand samples is given in Table I.

Table I. The Zonation of the Main Species of Crustacea

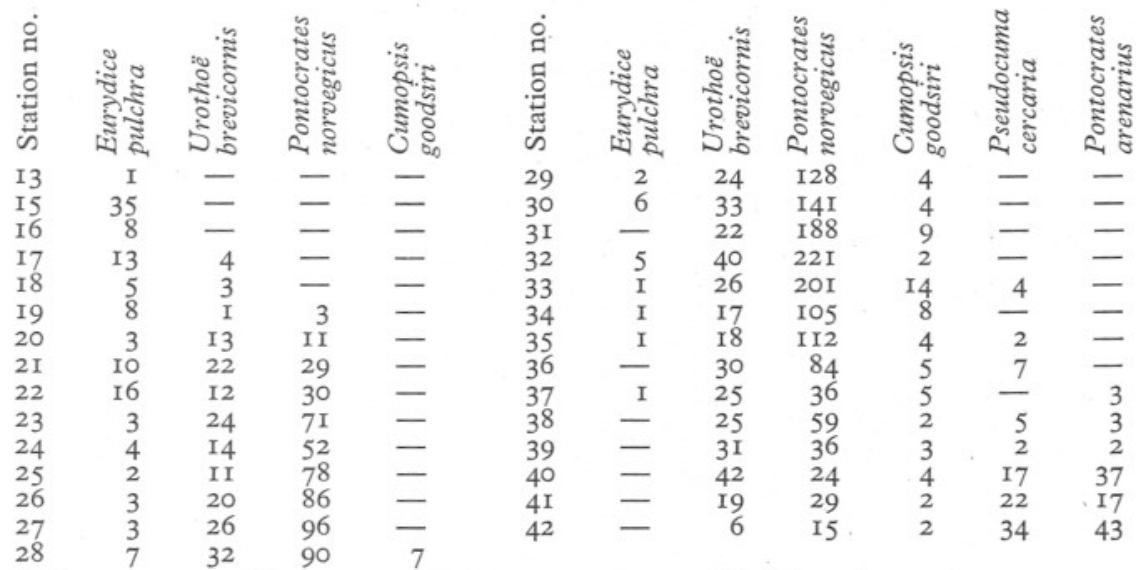

High-water neap tide occurs at St. I4, approximate mid-tide at St. 2I, low-water neaps at St. 39.

An analysis of the night tow-net samples for the four species of the genus Bathyporeia has been given (Watkin, I939). Consequently the detailed figures of the distribution of these species in the sand samples are omitted. Further, only those species which occur in the night tow-net samples and whose distribution extends over several stations are included. The following species 
also occurred: Lamprops fasciata St. 35, one; Iphinoë trispinosa St. 42, two; Nototropis swammerdami St. 42, two; Megaluropus agilis St. 42, one; and Crangon vulgaris St. 24, one.

The first five stations from the high-water mark of spring tides contained no macrofauna. Bathyporeia pilosa appeared at St. 6 with a centre of maximum abundance at Sts. I2 and I3, gradually disappearing to St. 22. Haustorius arenarius ranges over Sts. I0-I4 and spasmodically to the low-water mark of spring tides. The high-water mark of neap tide occurs at St. I4 (recorded by Mr Elmhirst on May I2 I939, calm sea with a slight north-westerly breeze). Eurydice pulchra extends from the upper neap-tide level with a maximum at St. I5 and occurs continuously in varying abundance to St. 37 with a definite tendency to be more abundant in the upper half of the neap-tide range. Urothoë brevicornis first appears at St. I7 and continues to the low-water mark of spring tides with a tendency to be more abundant in the lower half of the neap-tide range. The low-water mark of neap tide occurs at St. 39. Pontocrates norvegicus extends from St. I9 in gradually increasing abundance to St. 32, to be followed by a gradual decrease to low-water mark. Bathyporeia pelagica first appears at St. 24, increases to a maximum over Sts. 3I-35 and disappears after St. 40. Thus this species and Pontocrates norvegicus have a similar centre of maximum abundance in the lower half of the neaptide range. The former is distinctly an intertidal species in this bay, but the latter may extend beyond the low-water mark of spring tides. Cumopsis goodsiri is never abundant, but is represented at every station from 28 to low-water mark, and thus does not occur above mean sea-level. Pseudocuma cercaria does not appear until St. 33 and does not become abundant until St. 40, i.e. below the low-water mark of neap tides. Bathyporeia elegans first appears at St. 35 and extends to the low-water mark of spring tides with a centre of abundance near low-water mark. B. guilliamsoniana also appears in the last six samples, but is known to be definitely more abundant beyond low-water mark. Pontocrates arenarius appears in the last seven samples with a suggestion that its centre of abundance is near low-water mark.

\section{The Fauna of the Night Tow-Net SAmples}

Table II gives the dates on which the samples were obtained, the time the sample was taken, the time of afternoon high tide, the age of the moon in days and the number of individuals of the most abundant species per sample. Table III shows the data for the most important species from the point of view of zonation and also summarizes the results of a detailed analysis of the maturity of each individual.

Pontocrates norvegicus and P. arenarius.

$P$. norvegicus was present in thirty out of the forty-eight samples and $P$. arenarius in nine, with six samples showing a mixture of the two species. However, in all the six samples containing both species one of the species is 
Table II. Number of Individuals of the Most

Abundant Species in Each Sample

\begin{tabular}{|c|c|c|c|c|c|c|c|c|c|c|c|c|}
\hline 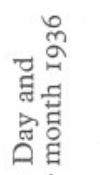 & 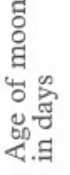 & 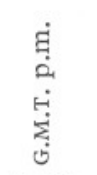 & 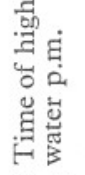 & 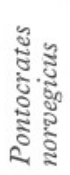 & 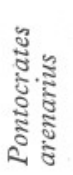 & 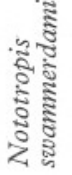 & 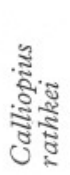 & 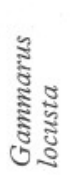 & 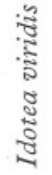 & 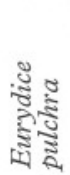 & 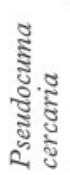 & 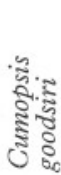 \\
\hline 7. i. & I4 & I0.00 & II. 44 & $\bar{x}$ & - & - & - & 2 & - & 3 & - & - \\
\hline I5. i. & $\begin{array}{l}22 \\
28\end{array}$ & $\begin{array}{l}7.30 \\
6.45\end{array}$ & 4.16 & $\begin{array}{r}\text { II } 7 \\
28\end{array}$ & 二 & 2 & 二 & $\begin{array}{r}6 \\
18\end{array}$ & 二 & - & $\bar{z}$ & 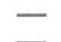 \\
\hline $\begin{array}{l}\text { I. i. } \\
\text { I2. ii. }\end{array}$ & 20 & $\begin{array}{l}.45 \\
8.30\end{array}$ & $\begin{array}{c}\text { IO. } 32 \\
3.7\end{array}$ & $\begin{array}{r}28 \\
4\end{array}$ & $\overline{28}$ & $\begin{array}{l}\text { I } \\
\text { IO }\end{array}$ & - & $\begin{array}{l}18 \\
25\end{array}$ & ${ }_{I}$ & $2^{2}$ & $\overline{76}$ & \\
\hline 13. ii. & $2 I$ & 7.00 & 3.37 & IIO & - & I & & I & - & - & 70 & \\
\hline 27. ii. & 6 & 7.40 & 3.32 & II & - & 244 & 2 & 1656 & $3 \mathrm{I}$ & - & - & \\
\hline 4. iii. & I2 & II.00 & 10.38 & - & - & - & - & I & & I & - & \\
\hline I9. iii. & 27 & 9.00 & 9.34 & - & - & - & - & - & - & - & - & 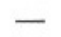 \\
\hline 24. iii. & 2 & 4.30 & 00 & 二 & - & - & - & - & - & - & - & - \\
\hline 29. iv. & 9 & IO.I5 & 6.53 & $\overline{-}$ & - & - & - & 33 & - & 2 & - & 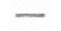 \\
\hline 30. iv. & Io & I0.15 & 8.10 & 125 & - & - & - & 36 & I & 4 & - & - \\
\hline I. v. & II & IO.I5 & 9.13 & IO & - & - & - & 28 & 2 & I & - & - \\
\hline 2. v. & I2 & I0.15 & IO. 2 & 2 & 二 & 二 & - & 42 & - & 7 & - & - \\
\hline 3. v. & I3 & IO.I5 & I0.44 & 2 & 二 & I & I & 5 & 2 & $\begin{array}{r}9 \\
12\end{array}$ & I & - \\
\hline 9. v. & $\begin{array}{l}19 \\
24\end{array}$ & $\begin{array}{l}\text { I0.15 } \\
\text { IO.I5 }\end{array}$ & I. 55 & $\underline{9 I}^{-1}$ & 二 & I & I & I & 2 & 12 & 1 & - \\
\hline $\begin{array}{l}\text { I4. v. } \\
\text { I5. v. }\end{array}$ & $\begin{array}{l}24 \\
25\end{array}$ & $\begin{array}{l}\text { I0.15 } \\
\text { I0.15 }\end{array}$ & $\begin{array}{l}5.55 \\
7.9\end{array}$ & 59 & - & 3 & 二 & $\begin{array}{r}17 \\
115\end{array}$ & 55 & $\begin{array}{r}17 \\
2\end{array}$ & I & 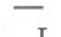 \\
\hline $\begin{array}{l}\text { 15. v. } \\
16 . \mathrm{v} \text {. }\end{array}$ & 26 & I0.15 & 8.17 & 42 & - & I & - & 35 & 27 & 12 & 1 & 1 \\
\hline I7. v. & 27 & IO.I5 & 9.19 & I3 & - & - & - & 23 & 4 & I5 & - & - \\
\hline 2I. v: & 2 & IO.I5 & 0.22 & I9 & - & - & - & - & $T$ & 22 & - & - \\
\hline I. vi. & 13 & I0.15 & 10.0 & - & - & - & 一 & - & - & I & - & - \\
\hline Io. vi. & 22 & II.00 & 3.49 & 120 & $\overline{5}$ & $\overline{2 \pi}$ & - & II & I & 2 & - & 2 \\
\hline I2. vi. & 24 & 10.30 & $5 \cdot 3$ & 6 & I67 & $3 \mathrm{I}$ & - & 4I & 5 & I & 72 & I \\
\hline I6. vi. & 28 & 10.30 & 9.52 & - & 二 & - & - & 一 & & - & & \\
\hline 23. vi. & 5 & I.00* & 3.12 & - & $\overline{-}$ & - & - & 5 & - & I & - & - \\
\hline 26. vi. & 8 & II.०0 & 5.12 & 2 & 219 & II & - & 42 & - & 一 & 90 & - \\
\hline 27. vi.: & 9 & I.00* & 5.58 & 479 & I & 5 & - & $3 \mathrm{I}$ & I & I & I & 29 \\
\hline 2. vii. & I4 & II 1.00 & 10.53 & - & 二 & 二 & 二 & 2 & I & - & - & - \\
\hline I4. vii. & 26 & II 1.00 & 8.23 & 44 & - & - & - & I28 & 2 & I & $\overline{\tau s}$ & - \\
\hline 2I. vii. & 4 & II.OO & 2.9 & 786 & 7 & 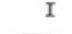 & 二 & 13 & - & $\overline{2}$ & 15 & 23 \\
\hline 31. vi & I4 & II.00 & 10.30 & $\overline{1}$ & 二 & 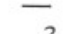 & - & 6 & 2 & 24 & 一 & - \\
\hline I2. vili. & 26 & II 1.00 & $8.1 \mathrm{I}$ & 235 & - & 2 & I & 102 & 3 & 3 & 1 & 9 \\
\hline 2I. vili. & 5 & II.OO & $2.4 \mathrm{I}$ & $2 \mathrm{I}$ & 103 & IOI & I & I2I & & 2 & 80 & \\
\hline 3I. viii. & I5 & I I .०O & II. 3 & - & 5 & - & - & 6 & - & 7 & 2 & 一 \\
\hline 8. ix. & 23 & 9.45 & & & 43 & 7 & - & 46 & 2 & I & 227 & - \\
\hline I5. ix. & I & I0.00 & 0.6 & I5O & - & I & - & I & I & I8 & 2 & 3 \\
\hline 24. ix. & I0 & I0.00 & 5.28 & I8 & 一 & 3 & I & 2 & - & I & I & \\
\hline 30. ix. & I6 & 10.00 & II. 50 & 84 & 70 & 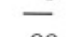 & - & - & - & 3 & 2 & 7 \\
\hline $5 . x$. & $2 \mathrm{I}$ & 10.30 & 3.9 & - & I8 & 99 & 8 & 9 & - & I & 259 & \\
\hline 20. x. & 6 & 10.30 & $2.4 \mathrm{I}$ & 70 & - & 3 & - & 3 & 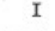 & 13 & - & 4 \\
\hline 28. x: & I4 & I0.30 & 10.38 & - & 一 & - & - & I & - & 2 & - & \\
\hline 7. xi. & 24 & 8.30 & 7.0 & - & - & - & - & 7 & - & 3 & - & \\
\hline I2. xi. & 29 & I0.30 & II. 24 & 109 & 一 & 3 & 二 & 503 & $3 \mathrm{I}$ & 4 & 3 & - \\
\hline $25 . \times 1$ & $\begin{array}{l}\text { I2 } \\
28\end{array}$ & 8.30 & $\begin{array}{r}9.14 \\
0.58\end{array}$ & 二 & 二 & 二 & 二 & $\bar{I}_{5}$ & - & 2 & 二 & 二 \\
\hline II. $\mathrm{X}$ & 28 & II. 45 & 10.5 & - & 二 & 二 & $-\frac{2}{2}$ & $\begin{array}{l}15 \\
10\end{array}$ & - & 2 & & \\
\hline $\begin{array}{l}\text { I4. Xi1. } \\
\text { I4. xii. }\end{array}$ & $\begin{array}{l}2 \\
2\end{array}$ & $\begin{array}{r}8.45 \\
\end{array}$ & 0.25 & $\begin{array}{l}8 \\
2\end{array}$ & - & - & - & 2 & 3 & $\begin{array}{ll}12 \\
16\end{array}$ & 二 & I \\
\hline 22. xii. & I0 & 7.30 & 6.19 & - & - & - & - & - & - & 2 & - & - \\
\hline & & & 2776 & 591 & 530 & 22 & $3 \mathrm{I} 5 \mathrm{I}$ & I 77 & 230 & 833 & 80 \\
\hline
\end{tabular}


represented by a few individuals only. The samples are reasonably pure to one species. It is to be expected that samples taken towards low-water mark would contain both species, since the analysis of the sand fauna shows that they overlap from St. 37 seawards. P. arenarius is present in considerable numbers only in those samples taken between L.w.N. and L.W.S. (Table III), e.g. I2. vi. 36 and 26. vi. 36 . The sample of 31 . viii. 36 is aberrant, it was taken near the high water of a spring tide and was the only occasion when this species was taken outside its zone, as shown by the sand samples. Similarly, the samples containing $P$. norvegicus in abundance were those taken in the middle and lower third of the neap-tide range, e.g. 21. vii. 36 , and 27. vi. 36 . The samples taken at high water contain none or very few. Thus both these

Table III. Summary of the Zonation and Maturity of some Species
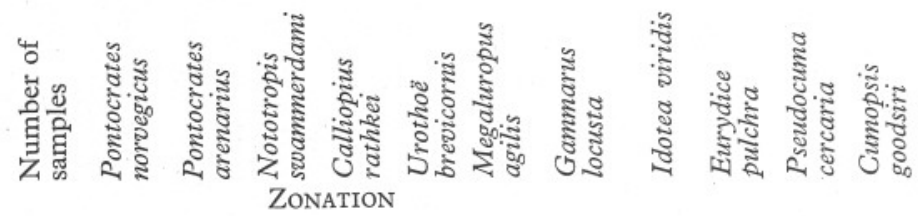

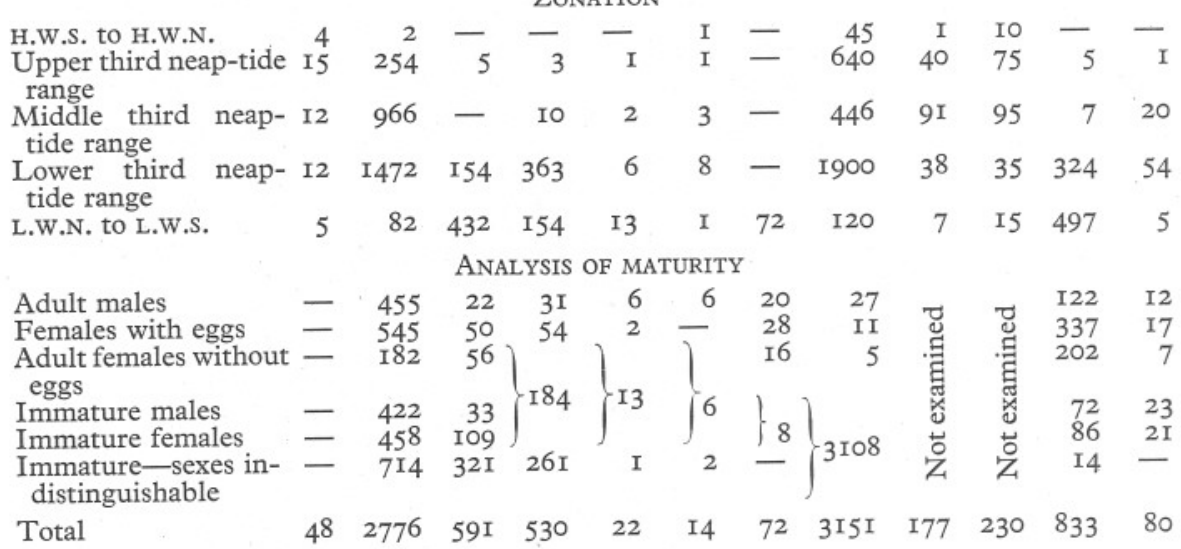

species retain their sand zonation when swimming in the intertidal waters. A comparison with those samples containing Bathyporeia (Watkin, I939) shows that $P$. arenarius is present in the same samples as those containing $B$. guilliamsoniana and $B$. elegans and only partly with those containing $B$. pelagica, whilst $P$. norvegicus overlaps in the main with $B$. pelagica and partly with $B$. pilosa.

Bearing in mind that some of the sample are taken outside its tidal range, the presence of $P$. norvegicus in thirty out of the forty-eight samples suggests that it is migratory throughout the year. Its density, however, on various nights differs considerably.

A detailed examination of the individuals showed that in $P$. norvegicus all stages of maturity are present at all times of the year. Egg-bearing females 
and adult males were recorded for each month and the spasmodic appearance of numbers of young forms suggests that broods are produced at definite times. The data are not full enough to draw definite conclusions on the number of broods produced, but they suggest that one brood per month is released. Similar remarks also apply to $P$. arenarius, but no samples, apart from that of I2. ii. 36, were taken within their zone during the first six months of the year.

The totals (Table III) show that the migrant population of $P$. norvegicus consists of $19.6 \%$ egg-bearing females, I6.4\% adult males, $6.5 \%$ non-eggbearing females, $31 \cdot 7 \%$ immature forms of both sexes and $25 \cdot 7 \%$ young forms. Thus $42.5 \%$ are adults. The preponderance of adult males is not nearly so marked as in Bathyporeia, where $42 \%$ were adult males. The percentage of adult females is, however, somewhat higher, $26 \cdot \mathrm{I} \%$ as compared with $15 \%$. Comparing these figures with those obtained for the sand population, taken in late March and early April before the production of the new season's broods has reached a high level, when $6 \mathrm{I} \%$ were adults with $5 \%$ adult males, it is seen that there is a tendency for adult males to be more abundant in the tow-net samples. The individual samples are somewhat variable in their population, but where the number of individuals in a sample is high the population consists of a mixture of forms in all stages of maturity.

The migrant population of $P$. arenarius shows a smaller percentage of adult males and immature males than $P$. norvegicus, but otherwise retains the same general features.

The data are not sufficient to draw definite conclusions in regard to lunar periodicity. Those given in Table II show irregularity during the first half of the lunar month but become more regular during the last Io days of the month, with a suggestion that the species becomes more abundant in the periods immediately preceeding the new and full moon.

Fage (I933) records both species in his night tow-nettings "autour d'un foyer lumineux" at Concarneau and Port-Vendres; the numbers are small with adult males predominating.

\section{Urothoë brevicornis (Tables I and III).}

It has been noted that this species occurs abundantly in all the sand samples from St. I7 to low-water mark. Its occurrence in the night tow-net samples is, however, very spasmodic. A total of fourteen individuals is recorded from nine samples; they are spread over the whole range in which this species occurs in the sand samples, showing, as in the sand samples, a tendency to be more abundant in the lower third of the neap-tide range. The fourteen individuals comprise six adult males, one adult female, five immature females and two young forms. Fage (I933) records other species of this genus in his night tow-nettings "autour d'un foyer lumineux", particularly at Concarneau. All the specimens were males. Russell (I925) records the genus in samples taken up to $50 \mathrm{~m}$. depth in the waters of the English Channel 
on a moonlight night in July, and notes that it differs from other amphipods in appearing in the surface waters at 9 p.m. Tattersall (19I3) records $U$. marina and $U$. elegans as night migrants in the Clare island survey. Thus there is considerable evidence to show that species of this genus are migratory at night; but none of the records indicate the presence of egg-bearing females.

The allied form Haustorius arenarius is recorded in the sand samples but not in the tow-net samples. Dennell (1933) remarks that "Haustorius apparently may forsake the sand...to swim freely" and under laboratory conditions it was observed to do so between the hours of II p.m. and 6 a.m. It is to be expected that a species so modified for a swimming habit should have occurred in the samples, but I can find no reference to its occurrence as a night migrant.

\section{Gammarus locusta (Tables II and III).}

This species inhabits "water of some fathoms depth" (Elmhirst, 1932) and is usually regarded as living amongst algae. It is thus a migrant into Kames Bay from its known habitat in deeper waters, and is the predominant migratory amphipod from outside waters.

From its presence in forty out of the forty-eight samples it is reasonable to suppose that it is a tidal migrant throughout the year at all phases of the moon. Its abundance is, however, exceedingly variable. Note may be made of the sample of 27. ii. 36 with I656 individuals and that of I2. xi. 36 with 503 individuals, with many samples containing less than ten. The samples with high numbers do not seem to bear any relationship to the state of the tide at the time they were obtained. They occur in the low-water, mid-tidal and high-water samples. Similarly, they are spread evenly throughout the year. When the data for the whole year are plotted against a lunar month it is seen that there is a distinct tendency for the numbers to increase as the period of new moon approaches and to a less extent towards the period of full moon, if the one exceptional sample of 1656 individuals, taken on the sixth day of the lunar month, is omitted. The numbers fall during the immediate periods of full and new moon.

A striking feature of the results, which is characteristic of every sample, is the dominance of the immature stages and the progressive reduction in numbers as size increases. Thus of $315 \mathrm{I}$ individuals $1495(47 \%)$ are under $3 \mathrm{~mm}$. I276 (4I \%) from 3 to $5 \mathrm{~mm}$., 280 (9\%) from 5 to $7 \mathrm{~mm}$., $69(2 \%)$ from 7 to $9 \mathrm{~mm}$. and $3 \mathrm{I}(\mathrm{I} \%)$ over $9 \mathrm{~mm}$. Blegvad (I922) in his account of the life history of this species in Danish waters records that males attain full maturity at a size of Io $\mathrm{mm}$. and some females may attain maturity at $6 \mathrm{~mm}$. Thus this species is characteristically a migrant in its young stages. It should be noted, however, that forty-three, or $\mathrm{I} \cdot 4 \%$, of the individuals are adults with the males predominating, twenty-seven of the forty-three. Of the sixteen adult females eleven carried eggs in the brood pouch. The presence of a few adults prompts the suggestion that possibly they are more numerous 
in the waters over their immediate habitat and that they do not perform such extensive horizontal migrations as the young forms. Further sampling should prove interesting. Fage (1933) records a somewhat similar population at Concarneau, in which the young forms predominate over a few adult males.

$\mathrm{Mr}$ Elmhirst is of the opinion that this species comes in when there is much drift algal detritus in the tidal waters.

Marinogammarus spp. occurred in five samples only: No. 8, one; No. I9, one; No. 42 , one; No. 46 , one; No. 47 , four. Of the eight individuals seven were young forms with one egg-bearing female. The data are scanty but the same general features as in $G$. locusta are indicated.

Nototropis swammerdami.

The habitat of this species is amongst the sublittoral algae. Table II shows that it occurred in twenty of the night tow-net samples, which indicates that it is migratory throughout the year; but as with the other species the extent of the migration is very variable. Three of the samples account for $84 \%$ of the total number recorded. The samples in which it occurs were taken at all stages of the tide, but it only occurs in abundance in those taken in the lower third of the neap-tide range and those near low water. Continuous sampling in this region would probably show its occurrence to be more regular. All stages of maturity are represented (Table III), with breeding females present only in the samples with a large number of individuals and forming $10 \%$ of the total. Adult males are relatively scarce, $6 \%$ of the total, with the young forms predominating. Thus this species shows migratory features similar to those of Gammarus locusta. Fage (1933) records both $N$. guttatus and $N$. swammerdami, the population consisting mainly of adult males, and Tattersall records $N$. vedlomensis as a night migrant in the Clare Island survey. Other authors also record its pelagic habit.

Calliopius rathkei.

Nine samples scattered over the year contain this species in small numbers. The data are scanty but suggest that it is more numerous during the winter than the summer months, and, as with Nototropis swammerdami, it is abundant in the low-water samples. The habitat is amongst sublittoral algae; Sars (I89I) records that it occurs in Norwegian waters "in great shoals, swimming actively near the beach, and ascending it according as the tide flows up". Tattersall records it as a night migrant.

Apherusa spp.

This genus is represented by the three species $A$. jurinei (M.-Edw.), ten individuals in seven samples, $A$. bispinosa (Bate), six individuals in three samples, and $A$. cirrus (Bate), one individual, occurring from May to December. It is noteworthy that the individuals are either adults or immature forms and none of the adult females were egg-bearing. Many authors record the pelagic 
habit of the species in this genus. Thus Russell (I927) records the abundance of $A$. ovalipes and $A$. cleve $i$ in the day-time in the waters of the English Channel; they were absent from the surface layers but abundant from $20 \mathrm{~m}$. depth, Io min. hauls giving 3480,6480 and 6940 individuals. In dealing with hauls taken at night-time in summer, he further records (I93I), that during 1925 (and probably showing the same behaviour in 1926) there was a marked upward movement at night, the species being evenly distributed from the surface downwards. Samples taken throughout the year I930 and part of I93I (Russell, I934) show the species to be abundant from late June to September, reappearing in April 193I. Fage lists A. bispinosa at Concarneau with males and females in almost equal numbers and notes that the species is exceptional in that its abundance is not affected by the light employed.

\section{Other amphipods.}

Attention may be drawn to Dexamine thea, seventeen individuals from six samples, and Stenothoë monoculoides, seven individuals from five samples, as adding to the list of algal dwellers which may be included under the species performing a night migration. The data for the sand dwellers Megaluropus agilis (Table III) and Periculodes longimanus, six individuals from two samples, does not represent the extent of their migration, since Elmhirst (1932) has shown that samples taken at two fathoms depth near the low-water mark of spring tides yield these two species in considerable numbers. The samples were taken on a night in March and again in June and successive sampling at $3 \mathrm{hr}$. intervals from $6 \mathrm{p} . \mathrm{m}$. to $6 \mathrm{a} . \mathrm{m}$. gave maximum hauls at $9 \mathrm{p} . \mathrm{m}$. and midnight. Metaphoxus fultoni was recorded in one sample only, but its occurrence as a night migrant in the waters of the Firth of Clyde is recorded by Patience (1909) in samples taken during July at one fathom from the bottom. Males were more abundant than females. Podoceros falcatus, three individuals from three samples, Erichthonius braziliensis, two individuals from two samples, Siphonoecetes colleti, two individuals, Phtisca marina, one individual, Hyale sp. must be regarded as chance occurrences due to storm action.

\section{Eurydice pulchra.}

This species occurs in thirty-seven of the samples (Table II). The samples indicate its presence throughout the year and at all tide levels, with a tendency, shown also by its distribution in the sand, to be more abundant in the upper and middle portion of the neap-tide range. It is probable that this species is as equally a day migrant as a night migrant, although actual figures are not available to substantiate this statement. Observations carried out on this species in the laboratory show that it obtains food by capturing other living organisms in the plankton, tearing a rent in their skin and disembowelling them by the use of the anterior peraeopods. On the beach it may be observed that they rise out of the sand with the inflowing tide, proceed to feed im- 
mediately and sink again into the sand with the retreating tide. The migration into the tidal waters is thus essentially a feeding one. Details of the annual life cycle are not available but casual observations suggest that two broods, a spring and an autumn, are produced.

\section{Idotea viridis.}

The occurrence of this species in twenty-one of the samples suggests that it is migratory throughout the year from its habitat in the littoral and sublittoral algae. The numbers in the samples are very variable, four of them accounting for $8 \mathrm{I} \%$ of the total. A notable feature is the dominance of young forms with the numbers rapidly decreasing as size advances. The figures are, under $2 \mathrm{~mm} .60$, at 3 and $4 \mathrm{~mm}$. 73, at 5 and $6 \mathrm{~mm} .32$, at 7 and $8 \mathrm{~mm}$. 4, over $8 \mathrm{~mm}$. 8. Thus those under $4 \mathrm{~mm}$. comprise over $75 \%$ of the total. Howes (1939) records that in a saline lagoon in Essex this species attains maturity at $5 \mathrm{~mm}$. in the female and $6 \mathrm{~mm}$. in the male, although very few are mature at this size. Assuming that this population attains similar sizes the absence of the adult stages becomes notable. One egg-bearing female was obtained. When the data for the whole year are plotted against a lunar month it is noted that the species occurs throughout the month but with a definite tendency to be more abundant in the period immediately preceeding the new moon. The migrations of this species recall those recorded here for Gammarus locusta and a comparison of the sample numbers shows that the maximum number of both species occurs in the same samples. Elmhirst is definitely of the opinion that the occurrence of $I$. viridis is associated with drift weed in the tidal waters. Thus the amount of algal detritus must be considered as a contributory factor in the migration of both species.

Fage (1933) draws a distinction between the pelagic migration of the Cirolanidae on the one hand and the Idoteidae on the other. In the former the egg-bearing females always remain associated with their "substratum" whatever that may be, and the pelagic migrants are either males or "young" forms, whilst in the latter the thigmotropism which associates them with their substratum during the day is obscured at night-time and all stages of maturity are represented in the night migrant population. This conclusion is partially substantiated by the above observations on Eurydice pulchra and I. viridis.

\section{Cumopsis goodsiri.}

Table I shows that this species occurs in the sand samples from St. 28 to low water mark, and, although never abundant, it occurs in every sample. Table II shows that it was present in eleven of the tow-net samples between May and December but only in numbers during late June and July. The samples in which it occurs were taken mainly within its range as shown by the sand samples, its abundance occurring in the lower third of the neap-tide range; but its absence from many samples suggests that it is spasmodic in its 
migratory habits. Of the eighty individuals obtained seventeen were eggbearing females and twelve adult males, with immature forms of both sexes predominating and young forms absent.

Pseudocuma cercaria.

Of the forty-eight samples sixteen include this species. It will be recalled that it only occurs in sand samples taken near low water. Similarly, it only occurs in numbers in those night tow-net samples taken either at the low-water level of spring tides or in the lower third of the neap-tide range. An occasional specimen occurs in the mid-tidal samples and exceptionally in the upper third of the neap-tide range. It must be regarded mainly as a tidal immigrant from the sand below low-water mark, although the centre of its abundance needs further investigation. It differs from other tidal immigrants in being restricted to low water. Many authors have commented upon the relationship between cumaceans and moonlight. The present data when arranged on a lunar month basis shows two definite peaks of density; the first over the 5 th-8th day and the second over the 20th-23rd days, thus suggesting an association with lunar illumination of a certain intensity.

Elmhirst (1932), in a series of samples taken every three hours from 6 p.m. to 6 a.m. on a night in March and again in June, shows that this species is abundant in the surface waters at low tide; but at high tide, when the lowwater level is covered by 2 fathoms of water, it is abundant near the sea floor and practically absent from the surface. His data further show that very few are carried in with the tide to high-water mark. The above observations substantiate in part the observations of Elmhirst, but in this investigation no depth samples were taken.

In Table III the sex and degree of maturity of the individuals are shown. The adult males were mainly of the "short antennae" type (Foxon, I936, p. 388). Very few "fully adult" males were found. The data show that eggbearing females are present from February to October and that they represent $40 \%$ of the total catch. If the adult females without eggs are included, the percentage rises to $65 \%$, adult males accounting for $9 \%$ only. Thus adults predominate, with immature males and females constituting the remainder of the catches. Young forms are practically absent. Foxon, giving counts made on previous collections in this area, records males as more abundant than females and Fage makes the same observation. Further work on more extensive collections is necessary before definite statements can be made.

\section{Other cumaceans.}

Two of the low-water samples contain Iphinoë trispinosa, which occurs in the sand from low-water mark to some depth. Diastylis rathkei was recorded once, Lamprops fasciata once, and Bodotria scorpioides was found in three samples. Russell (I93I) records the vertical movement of the last-named species at night-time. 


\section{Crangon vulgaris.}

Young forms of this species from 4 to Io $\mathrm{mm}$. in length occurred in eight samples from June onwards. The numbers were small and a total of only twenty individuals was recorded.

Attention may finally be drawn to occasional species other than the Crustacea. Young Pleuronectids less than $12 \mathrm{~mm}$. in length were present in five of the May samples, and other young fishes in some samples from May onwards. Young Nereids of $3-5 \mathrm{~mm}$. were present in the June and July samples and Scolelepis adults in four samples. The use of a coarse tow-net avoided most of the usual smaller plankton organisms, but occasional megalopa and zoea larvae, calanoid and harpacticid copepoda and medusae were found.

Of the forty-eight samples thirty-nine contained Mysids, mainly Schistomysis spiritus, in varying numbers and varying degrees of maturity, many of the samples containing numerous young forms. It is hoped that these will be analysed and reported on in due course.

\section{DisCUSSION}

As far as I am aware this series of samples, collected by Mr Elmhirst for the study of the night migrant macrofauna of the intertidal waters throughout a whole year, is the first of the kind which has been made. The main purpose of the work is to show that this field is a fruitful one for further investigation. It is not proposed to discuss in detail the possible factors which underlie the migration of the species either individually or as a whole, but rather to indicate the problems requiring further investigation and to show how this series of samples demonstrates the positions at which the collection of further samples should be made. The samples were taken, in all cases, at the edge of inflowing or outflowing tide. Thus the position of each sample is determined by the position of the tide when the sample was taken, and they have served to show the general outline of the problems involved. The main point that emerges, apart from the fact that the major part of the night migrant population consists of Crustacea, is that the population falls into two well-marked groups: (a) that which normally lives in the intertidal sand of the bay and becomes migrant at night-time, and $(b)$ that which is carried in to the bay by the inflowing tide from other habitats. Thus, as an auxiliary study, it is necessary to know the fauna of the intertidal soil and also that of the adjacent deeper water habitats which may be (I) sand or mud habitats, or (2) algal habitats, or both. This investigation shows that both habitats contribute to the migrant population. To complete the analysis of the migrant fauna it is necessary to obtain samples of the microfauna, which in addition to the usual plankton organisms will consist of such forms as Harpacticids (Elmhirst, I935), and also to obtain a knowledge of the fishes which both as adults and 
in their young stages may migrate inshore at night-time in varying numbers at the different seasons of the year (Elmhirst, 1935; Marshall et al. 1939). By such studies it will eventually be possible to build up a picture of the extensive activities which occur in intertidal waters at night-time.

The data given in this paper and previously for Bathyporeia show that the sand population retains its zonation when migrant in the intertidal waters, but that species which are migrant from outside habitats are distributed over the whole tidal range and show no zonation. Thus, Pontocrates norvegicus and $P$. arenarius and the four species of Bathyporeia only occur in those samples taken over their immediate habitat, whilst Gammarus locusta occurs in practically every sample. The further investigation of the intertidal sand species involves three lines of sampling: (a) a series taken above the highwater mark of neap tides which will include as the main species Bathyporeia pilosa, (b) a series taken just below the mean sea level, i.e. a mid-tidal sample, which is the centre of abundance of Pontocrates norvegicus and Bathyporeia pelagica, and $(c)$ a series at the low-water mark of spring tides to include Bathyporeia elegans, Pontocrates arenarius, Pseudocuma cercaria and Cumopsis goodsiri as the dominant species. These three series of samples would also supply much information about the migrants from the deeper water habitats, but they would need supplementing by samples taken over their respective habitats to show whether the population differs at various points along the migratory path. Gammarus locusta is a suitable species in this respect. The sampling in deeper waters must include depth samples as well as surface samples; Pseudocuma, for instance, is known to remain associated with the water immediately over its habitat and not to rise in numbers to the surface.

Though the data here presented furnish evidence that the behaviour of the species changes at different times of the year, the apparent association of many species with varying lunar light intensities needs as continuous a series of samples as possible. Much further evidence is also required in regard to the time when the species rise, to show if it bears any relationship to the time of the rise of the moon and if it differs on moonlight or moonless nights. This factor may, however, be of considerably less significance than that of the degree of calmness or roughness of the tidal waters. It is probable that there is a close relationship between the calmness of the tidal waters and the degree of emergence of the species from their habitats. In view of all the factors involved, the collection of a perfect series of samples becomes almost an impossibility.

The results for the various species show that their behaviour does not follow any generalized form; but a broad distinction may be drawn, in the amphipods, between the intertidal sand-dwelling forms and the immigrant species. The migrant population in the former, typified by Pontocrates and Bathyporeia, shows all stages of maturity, whilst in the latter, typified by Gammarus and Nototropis, there is a predominance of young forms with the adults taking but little part in the migration. In the intertidal sand-dwelling 
forms adults tend to predominate over the young, with the adult males showing a stronger migratory tendency than the females. The reasons for this difference in behaviour can only be assumed. It may be imagined that the behaviour in both instances serves as a means of dispersal but with a difference in the age of the dispersal phase. It may be that the sand-living forms migrate to form pairs, while this may be possible amongst algal dwellers without the necessity of migration. A more detailed study of the relationship of the species to their habitat is needed, and of their reproductive habits. The latter are known for G. locusta from the work of Blegvad, and it is known that many sand-dwelling species feed whilst buried in the sand, and do not migrate for the purpose of obtaining food. In Eurydice, however, which is a day migrant as well as a night migrant, the movement is essentially a feeding one and the absence of egg-bearing females indicates that its main purpose is not that of reproduction.

The behaviour of the various species in regard to the lunar cycle shows that Pontocrates, Bathyporeia and Gammarus are similar; this suggests that a factor other than feeding and reproduction may be causative, and the difference in the time of appearance in the lunar cycle between the species of these genera and Pseudocuma suggests that the same factor may affect different species in different ways.

\section{SUMMARY}

The faunal analysis of forty-eight samples taken with a coarse tow-net across the intertidal waters of Kames Bay during 1936 shows that the night migrant crustacean population falls into two well-marked groups: (a) those species which live in the intertidal sand and perform simple vertical migrations at night-time into the intertidal waters, and $(b)$ those which are carried in by the tide into the intertidal area from various habitats which lie beyond the low-water mark of spring tides. In the former group the species of the genera Bathyporeia and Pontocrates are dominant and they retain their zonation as migrants, the population consisting of individuals in all stages of maturity. This is in sharp contrast to the latter group, typified by Gammarus locusta and Idotea viridis, which occur over the whole tidal range with a population in which the young immature stages are dominant. The Haustoriids Urothoë brevicornis and Haustorius arenarius occur as inhabitants of the sand, the former appearing occasionally in the tow-net samples and the latter absent from them. The Cirolanid Eurydice pulchra performs both day and night migration for the purposes of feeding.

Discussion of the results indicates the lines along which further investigations may be carried out. 


\section{REFERENCES}

Blegvad, H., 1922. On the biology of some Danish gammarids and mysids. Rept. Danish Biol. Station, Vol. xxvIII, pp. I-I03.

Dennell, R., I933. The habits and feeding mechanism of the amphipod Haustorius arenarius Slabber. Fourn. Linn. Soc. Zool. London, Vol. xxxviII, pp. 363-88.

Elmhirst, R., I93I. Studies on the Scottish marine fauna. The Crustacea of the sandy and muddy areas of the tidal zone. Proc. Roy. Soc. Edin., Vol. LI, pp. I6975.

1932. Quantitative studies between tide marks. Glasgow Naturalist, Vol. x, pp. 52-62.

I935. Inshore fish feeding ground. Ann. Rept. Scott. Mar. Biol. Assoc. I934-5, pp. 9-II.

FAGE, L., I933. Pêches planctoniques à la lumière effectuées à Banyuls-sur-Mer et à Concarneau. III. Crustacés. Arch. Zool. Expér. Gén., Vol. LXxvi, pp. ro5-248.

Foxon, G. E. H., 1936. Notes on the natural history of certain sand-dwelling Cumacea. Ann. Mag. Nat. Hist., Ser. Io, Vol. xvir, pp. 377-93.

Howes, N. H., I939. Observations on the biology and post-embryonic development of Idotea viridis (Slabber) from new England Creek south-east Essex. Fourn. Mar. Biol. Assoc., Vol. xxiII, pp. 279-310.

Marshall, S. M., Nicholls, A. G. \& ORR, A. P., I939. On the growth of young Herring in the Clyde. Fourn. Mar. Biol. Assoc., Vol. xxirI, pp. 427-55.

Patience, A., I909. On the genus Phoxocephalus. Glasgow Naturalist, Vol. I, pp. I. I634 .

RusSELl, F. S., I925. The vertical distribution of marine macroplankton. An observation on diurnal changes. Fourn. Mar. Biol. Assoc., Vol. xIII, pp. 769-809.

- I927. The vertical distribution of marine macroplankton. V. The distribution of animals caught in the ring-trawl in the daytime in the Plymouth area. Fourn. Mar. Biol. Assoc., Vol. xiv, pp. 557-608.

- I93I. The vertical distribution of marine macroplankton. XI. Further observations on diurnal changes. Fourn. Mar. Biol. Assoc., Vol. xvir, pp. 767-84. - 1934. The seasonal distribution of macroplankton as shown by catches in the 2 metre stramin ring-trawl in off-shore waters off Plymouth. Fourn. Mar. Biol. Assoc., Vol. xIX, pp. 73-81.

SARs, G. O., I89I. Crustacea of Norway. I. Amphipoda. Kristiana.

STEPHEN, A. C., 1928. Notes on the quantitative distribution of molluscs and polychaetes in certain intertidal areas on the Scottish coast. Proc. Roy. Phys. Soc., Vol. XXI, pp. 205-I6.

Tattersall, W. M., I9r3. Clare Island Survey. Amphipoda. Proc. Roy. Irish Acad., Vol. xxxi, pp. I-42.

WATkIn, E. E., I939. The pelagic phase in the life history of the amphipod genus Bathyporeia. Fourn. Mar. Biol. Assoc., Vol. xxin, pp. 467-8I. 


\title{
THE PRESERVATION OF FISHING NETS, TRAWL TWINES AND FIBRE ROPES FOR USE IN SEA WATER
}

\author{
By W. R. G. Atkins, Sc.D., F.R.S. \\ Head of the Department of General Physiology \\ at the Plymouth Laboratory \\ and \\ F. J. Warren \\ Technical Assistant
}

\section{INTRODUCTION}

Several papers of this series have already appeared; the last (1936) dealt with nets and its fellow, in collaboration with Prof. J. Purser, with ropes. The best of the methods already tested have now been pitted against new methods or modifications. In particular, preservation by means of cutch, fixed by various processes, received attention.

When considering the best preservative to use, regard must be paid to the thickness of the threads of the net or the diameter of the twines and ropes. With a fine thread, adherence to the relatively large surface may be more important than penetration; whereas with a rope penetration is first and foremost necessary, coupled of course with a low solubility in sea water. Adherence may be improved and leaching away reduced by a subsequent treatment, with tar for example.

The samples were treated in the Laboratory and taken to the sea water basin at Pier Cellars, on the Cornish side of the Sound beyond Plymouth breakwater. This small basin was nearly emptied each tide. In the 1936-7 tests the samples were always totally immersed, being suspended from ropes slung across the basin. In the later tests the ropes were so placed that the samples were out of the water for 3-4 hr. each tide. Some tests were interrupted by the war scare in the autumn of 1938 . The samples were replaced in December. All remaining exposures were, however, interrupted by the war in the autumn of 1939.

In order to avoid the use of heavy testing machines a lighter rope than before was used in these tests; all materials were, for uniformity, supplied by one firm, the Gourock Ropework Co., Ltd., as follows:

"Gourock" six thread three strand manila rope, breaking load $700 \mathrm{lb}$.

Six thread three strand "Yacht" manila rope, breaking load $500 \mathrm{lb}$., approximately 0.6 in. in circumference. 
"Gourock special" manila trawl twine, I50s (namely I50 yards to I lb. weight), I6o lb. breaking load.

Cotton netting, 32s/12 ply, Ioo mesh deep, 26 rows to the yard. The cotton yarn count is the number of hanks which weigh $\mathrm{I}$ lb., each hank being 840 yards in length; 32 s is therefore 26,880 yards per lb., so with I2 ply the length is 2240 yards per $\mathrm{lb}$.

The strength shown for the new samples is the average value as given by the maker. For samples under $100 \mathrm{lb}$. tensile strength a spring balance was used; this dial registered the maximum pull. For samples under $200 \mathrm{lb}$. a dial spring balance was used also, but the needle of this flew back at break, so the figure was hardly reliable to within Io $\mathrm{lb}$. The ropes tested were so attached, by loops, that only the length under test received any strain. All breaks were clear of the attachments. For samples which did not break in any portion at $200 \mathrm{lb}$., tension was applied by means of lead weights. Results shown are usually the average of two or three breaks, save with the lead. In some cases, however, one or more portions of sample exceeded the maximum tensile test that could conveniently be applied at the time. Two figures such as 89,93 and a third over 100 are shown in the tables as an average of $>94$.

\section{PRESERVATIVES AND THEIR APPLICATION \\ Coal distillation products}

Crude gas-works benzene, used as a solvent for copper soaps; this blackens iron vessels because it contains sulphur compounds.

Motor benzene, a purer solvent, Anglo-American Oil Co.

Creosote oil, purchased locally.

Coal tar from local gas-works; a very thick tar, becomes moderately dry in one month.

Coal tar, "Corroid tar", specially prepared for nets by Messrs Hardman, Hull; a less viscous tar, becomes moderately dry in a fortnight.

\section{"Coalite" low-temperature distillation products}

Crude phenol, b.p. I80-230 C., a dark mobile liquid.

A neutral oil, b.p. $170-230^{\circ} \mathrm{C}$. ("oil A"). Does not darken much on standing; has been extracted with alkali and with acid; kindly presented by the Director, Chemical Research Laboratory, Teddington, as was also "oil B".

"Oil B", b.p. $225-250^{\circ}$ C. at I4 mm. pressure, extracted like oil A.

Coalite neutral oil, b.p. 100-245 ${ }^{\circ}$ C.; sp. gr. 0.97I; alkali extracted, darkens on standing. Presented by Coalite Works, Gawber, Yorkshire, as were also other samples.

Coalite heavy neutral oil, b.p. $220-370^{\circ}$ C.; sp. gr. 0.975 ; alkali extracted.

Coalite middle oil, b.p. I80-220 C., with $47 \%$ crude tar acids; sp. gr. 0.966. 
Coalite heavy oil, b.p. $230-280^{\circ}$ C., with $39 \%$ crude tar acids; sp. gr. I.or 8.

Coalite low temperature tar, dries moderately in about 3 weeks, rather quicker than the more viscous local tar; all drying rates are approximate and vary with the conditions.

\section{Wood distillation products}

Not used in these tests, used formerly, see this fournal, I936, Vol. xx, p. 628 .

\section{Petroleum products}

White spirit is a distillate between $140-200^{\circ} \mathrm{C}$.; it is of low flash point (Shell Co.).

Kerosene or paraffin oil, distils at $150-300^{\circ} \mathrm{C}$.; it has a higher flash point, being prepared for domestic use (Shell Co.).

Petrol, as for motor cars (Anglo-American Oil Co.).

\section{Cutch varieties}

Cutch from the Bakau and Kenya Extract Co., probably a mangrove extract, but the company's representatives in Glasgow refused all information.

"Forestal brand" cutch, from the heart wood of the South American Quebracho tree, Quebrachia schinopsis lorentzii.

"Elephant brand" extract, from the bark of the South African mimosa or black wattle, Acacia decurrens var. mollissima. These are completely soluble in hot water. For analyses, see Atkins, 1936, p. 629. The samples and analyses were kindly supplied by the Forestal Land, Timber and Railways Co.

\section{Copper compounds}

Copper sulphate, crystals, commercial quality. For Olie's (I9I8) method use a I \% solution in water and add just enough ammonia solution to redissolve the precipitate; this requires about 44 volumes of ammonia solution (sp. gr. 0.88) for Iooo volumes of copper solution; the resultant liquid is a deep blue; it is used after cutch. Soak IO-I5 min., not longer; the solution is nearly decolorized by the net.

Mixed copper soap, containing stearate with oleate, palmitate and laurate, made by Messrs Lever Bros. and sold either ready for use or in a concentrated emulsion. For use with nets it is prepared to contain about $20 \%$ of creosote or of thick mineral oil. We are indebted to Lever Bros. for a number of samples.

Copper oleate, a dark green greasy solid, contains about $2 \%$ of added creosote as supplied by Messrs Wm. Bailey and Sons, Wolverhampton, who also kindly provided samples of resinate and naphthenate.

Copper resinate, a light green dry powder, clean to handle; not very soluble in petrol, soluble in benzol, solvent naphtha and in "oil A" (neutral low-temperature tar distillate). 
Copper naphthenate, a dark green greasy solid, sold for use usually in solvent naphtha or various petroleum oils. We have received samples from Messrs Bailey, the Brent Manufacturing Co. in various solvents, and have also obtained it from Scott, Bader and Co. whose source appears to be the Brent Co. It is on the market as "Cuprinol" of various grades. As a result of tests done here a certain proportion of coal tar is now incorporated with the quality sold for nets. It was first manufactured in Denmark many years ago, by Messrs Cuprinol.

A new grade of Cuprinol, specially prepared to give waterproofed fishing lines in the rivers of British Columbia was also tested. This dries with a gloss on the outside of the tin but is not brittle.

\section{Miscellaneous preserving agents}

Two organic mercurial preparations, kindly supplied through the "Pest Control Research Committee" and Imperial Chemical Industries, Ltd., were also tried. DS 836 was a miscible oil product, with mercury content $5 \%$. DS 837 was a paraffin oil solution, with mercury content $3.6 \%$. They were used diluted with water, I vol. to Ioo and I vol. to 70 respectively, giving $0.05 \% \mathrm{Hg}$.

"Shirlan" was also tried. It is an anti-mildew agent introduced by the British Cotton Industry Research Association for use on sized cloth. It was of course never intended for use in sea water.

A waterproofing process, the Velan treatment, was also tested. The process was applied as directed by the makers, Imperial Chemical Industries, Ltd., who also make Shirlan. Velan PF was used.

"Tectal" is a creosote preservative, prepared by Melanoid, Ltd. of Tipton, one of the Mond group. Through the courtesy of the Belfast Ropework Co., Ltd., we were provided with a sample and analysis, showing its relation to coal-tar oil.

$\begin{array}{lcc} & \text { Coal-tar oil } & \text { Tectal } \\ \text { Sp. gr. } & \mathrm{I} \cdot 03 & 0.99 \\ \text { Flash point } & 70^{\circ} \mathrm{C} . & 90^{\circ} \mathrm{C} . \\ \text { Boiling range } & 130-140^{\circ} \mathrm{C} . & 200-360^{\circ} \mathrm{C} . \\ \text { Phenols } & 10-15 \% & 35 \% \\ \text { Viscosity } & 2.5 & 1.6\end{array}$

\section{Results of Tests}

Experiments of 1937-8: tests with copper soaps (Table I)

The aim of the tests shown in Table I was to study the relative merits of copper soaps in various solvents and at various dilutions. A few other preservatives were also tried; the most effective of these on nets was a sample believed to have a modified cutch bichromate treatment, No. 28. This did as well as No. 22, copper resinate in tar, and as Lever's copper soap mixture in creosote oil. Very curiously both outlasted No. 9, copper oleate in tar, which is usually the best on nets. Since No. 28 did so well, special attention 
in the waters over their immediate habitat and that they do not perform such extensive horizontal migrations as the young forms. Further sampling should prove interesting. Fage (1933) records a somewhat similar population at Concarneau, in which the young forms predominate over a few adult males.

$\mathrm{Mr}$ Elmhirst is of the opinion that this species comes in when there is much drift algal detritus in the tidal waters.

Marinogammarus spp. occurred in five samples only: No. 8, one; No. I9, one; No. 42 , one; No. 46 , one; No. 47 , four. Of the eight individuals seven were young forms with one egg-bearing female. The data are scanty but the same general features as in $G$. locusta are indicated.

Nototropis swammerdami.

The habitat of this species is amongst the sublittoral algae. Table II shows that it occurred in twenty of the night tow-net samples, which indicates that it is migratory throughout the year; but as with the other species the extent of the migration is very variable. Three of the samples account for $84 \%$ of the total number recorded. The samples in which it occurs were taken at all stages of the tide, but it only occurs in abundance in those taken in the lower third of the neap-tide range and those near low water. Continuous sampling in this region would probably show its occurrence to be more regular. All stages of maturity are represented (Table III), with breeding females present only in the samples with a large number of individuals and forming $10 \%$ of the total. Adult males are relatively scarce, $6 \%$ of the total, with the young forms predominating. Thus this species shows migratory features similar to those of Gammarus locusta. Fage (1933) records both $N$. guttatus and $N$. swammerdami, the population consisting mainly of adult males, and Tattersall records $N$. vedlomensis as a night migrant in the Clare Island survey. Other authors also record its pelagic habit.

Calliopius rathkei.

Nine samples scattered over the year contain this species in small numbers. The data are scanty but suggest that it is more numerous during the winter than the summer months, and, as with Nototropis swammerdami, it is abundant in the low-water samples. The habitat is amongst sublittoral algae; Sars (I89I) records that it occurs in Norwegian waters "in great shoals, swimming actively near the beach, and ascending it according as the tide flows up". Tattersall records it as a night migrant.

Apherusa spp.

This genus is represented by the three species $A$. jurinei (M.-Edw.), ten individuals in seven samples, $A$. bispinosa (Bate), six individuals in three samples, and $A$. cirrus (Bate), one individual, occurring from May to December. It is noteworthy that the individuals are either adults or immature forms and none of the adult females were egg-bearing. Many authors record the pelagic 
habit of the species in this genus. Thus Russell (I927) records the abundance of $A$. ovalipes and $A$. cleve $i$ in the day-time in the waters of the English Channel; they were absent from the surface layers but abundant from $20 \mathrm{~m}$. depth, Io min. hauls giving 3480,6480 and 6940 individuals. In dealing with hauls taken at night-time in summer, he further records (I93I), that during 1925 (and probably showing the same behaviour in 1926) there was a marked upward movement at night, the species being evenly distributed from the surface downwards. Samples taken throughout the year I930 and part of I93I (Russell, I934) show the species to be abundant from late June to September, reappearing in April 193I. Fage lists A. bispinosa at Concarneau with males and females in almost equal numbers and notes that the species is exceptional in that its abundance is not affected by the light employed.

\section{Other amphipods.}

Attention may be drawn to Dexamine thea, seventeen individuals from six samples, and Stenothoë monoculoides, seven individuals from five samples, as adding to the list of algal dwellers which may be included under the species performing a night migration. The data for the sand dwellers Megaluropus agilis (Table III) and Periculodes longimanus, six individuals from two samples, does not represent the extent of their migration, since Elmhirst (1932) has shown that samples taken at two fathoms depth near the low-water mark of spring tides yield these two species in considerable numbers. The samples were taken on a night in March and again in June and successive sampling at $3 \mathrm{hr}$. intervals from $6 \mathrm{p} . \mathrm{m}$. to $6 \mathrm{a} . \mathrm{m}$. gave maximum hauls at $9 \mathrm{p} . \mathrm{m}$. and midnight. Metaphoxus fultoni was recorded in one sample only, but its occurrence as a night migrant in the waters of the Firth of Clyde is recorded by Patience (1909) in samples taken during July at one fathom from the bottom. Males were more abundant than females. Podoceros falcatus, three individuals from three samples, Erichthonius braziliensis, two individuals from two samples, Siphonoecetes colleti, two individuals, Phtisca marina, one individual, Hyale sp. must be regarded as chance occurrences due to storm action.

\section{Eurydice pulchra.}

This species occurs in thirty-seven of the samples (Table II). The samples indicate its presence throughout the year and at all tide levels, with a tendency, shown also by its distribution in the sand, to be more abundant in the upper and middle portion of the neap-tide range. It is probable that this species is as equally a day migrant as a night migrant, although actual figures are not available to substantiate this statement. Observations carried out on this species in the laboratory show that it obtains food by capturing other living organisms in the plankton, tearing a rent in their skin and disembowelling them by the use of the anterior peraeopods. On the beach it may be observed that they rise out of the sand with the inflowing tide, proceed to feed im- 
mediately and sink again into the sand with the retreating tide. The migration into the tidal waters is thus essentially a feeding one. Details of the annual life cycle are not available but casual observations suggest that two broods, a spring and an autumn, are produced.

\section{Idotea viridis.}

The occurrence of this species in twenty-one of the samples suggests that it is migratory throughout the year from its habitat in the littoral and sublittoral algae. The numbers in the samples are very variable, four of them accounting for $8 \mathrm{I} \%$ of the total. A notable feature is the dominance of young forms with the numbers rapidly decreasing as size advances. The figures are, under $2 \mathrm{~mm} .60$, at 3 and $4 \mathrm{~mm}$. 73, at 5 and $6 \mathrm{~mm} .32$, at 7 and $8 \mathrm{~mm}$. 4, over $8 \mathrm{~mm}$. 8. Thus those under $4 \mathrm{~mm}$. comprise over $75 \%$ of the total. Howes (1939) records that in a saline lagoon in Essex this species attains maturity at $5 \mathrm{~mm}$. in the female and $6 \mathrm{~mm}$. in the male, although very few are mature at this size. Assuming that this population attains similar sizes the absence of the adult stages becomes notable. One egg-bearing female was obtained. When the data for the whole year are plotted against a lunar month it is noted that the species occurs throughout the month but with a definite tendency to be more abundant in the period immediately preceeding the new moon. The migrations of this species recall those recorded here for Gammarus locusta and a comparison of the sample numbers shows that the maximum number of both species occurs in the same samples. Elmhirst is definitely of the opinion that the occurrence of $I$. viridis is associated with drift weed in the tidal waters. Thus the amount of algal detritus must be considered as a contributory factor in the migration of both species.

Fage (1933) draws a distinction between the pelagic migration of the Cirolanidae on the one hand and the Idoteidae on the other. In the former the egg-bearing females always remain associated with their "substratum" whatever that may be, and the pelagic migrants are either males or "young" forms, whilst in the latter the thigmotropism which associates them with their substratum during the day is obscured at night-time and all stages of maturity are represented in the night migrant population. This conclusion is partially substantiated by the above observations on Eurydice pulchra and I. viridis.

\section{Cumopsis goodsiri.}

Table I shows that this species occurs in the sand samples from St. 28 to low water mark, and, although never abundant, it occurs in every sample. Table II shows that it was present in eleven of the tow-net samples between May and December but only in numbers during late June and July. The samples in which it occurs were taken mainly within its range as shown by the sand samples, its abundance occurring in the lower third of the neap-tide range; but its absence from many samples suggests that it is spasmodic in its 
migratory habits. Of the eighty individuals obtained seventeen were eggbearing females and twelve adult males, with immature forms of both sexes predominating and young forms absent.

Pseudocuma cercaria.

Of the forty-eight samples sixteen include this species. It will be recalled that it only occurs in sand samples taken near low water. Similarly, it only occurs in numbers in those night tow-net samples taken either at the low-water level of spring tides or in the lower third of the neap-tide range. An occasional specimen occurs in the mid-tidal samples and exceptionally in the upper third of the neap-tide range. It must be regarded mainly as a tidal immigrant from the sand below low-water mark, although the centre of its abundance needs further investigation. It differs from other tidal immigrants in being restricted to low water. Many authors have commented upon the relationship between cumaceans and moonlight. The present data when arranged on a lunar month basis shows two definite peaks of density; the first over the 5 th-8th day and the second over the 20th-23rd days, thus suggesting an association with lunar illumination of a certain intensity.

Elmhirst (1932), in a series of samples taken every three hours from 6 p.m. to 6 a.m. on a night in March and again in June, shows that this species is abundant in the surface waters at low tide; but at high tide, when the lowwater level is covered by 2 fathoms of water, it is abundant near the sea floor and practically absent from the surface. His data further show that very few are carried in with the tide to high-water mark. The above observations substantiate in part the observations of Elmhirst, but in this investigation no depth samples were taken.

In Table III the sex and degree of maturity of the individuals are shown. The adult males were mainly of the "short antennae" type (Foxon, I936, p. 388). Very few "fully adult" males were found. The data show that eggbearing females are present from February to October and that they represent $40 \%$ of the total catch. If the adult females without eggs are included, the percentage rises to $65 \%$, adult males accounting for $9 \%$ only. Thus adults predominate, with immature males and females constituting the remainder of the catches. Young forms are practically absent. Foxon, giving counts made on previous collections in this area, records males as more abundant than females and Fage makes the same observation. Further work on more extensive collections is necessary before definite statements can be made.

\section{Other cumaceans.}

Two of the low-water samples contain Iphinoë trispinosa, which occurs in the sand from low-water mark to some depth. Diastylis rathkei was recorded once, Lamprops fasciata once, and Bodotria scorpioides was found in three samples. Russell (I93I) records the vertical movement of the last-named species at night-time. 


\section{Crangon vulgaris.}

Young forms of this species from 4 to Io $\mathrm{mm}$. in length occurred in eight samples from June onwards. The numbers were small and a total of only twenty individuals was recorded.

Attention may finally be drawn to occasional species other than the Crustacea. Young Pleuronectids less than $12 \mathrm{~mm}$. in length were present in five of the May samples, and other young fishes in some samples from May onwards. Young Nereids of $3-5 \mathrm{~mm}$. were present in the June and July samples and Scolelepis adults in four samples. The use of a coarse tow-net avoided most of the usual smaller plankton organisms, but occasional megalopa and zoea larvae, calanoid and harpacticid copepoda and medusae were found.

Of the forty-eight samples thirty-nine contained Mysids, mainly Schistomysis spiritus, in varying numbers and varying degrees of maturity, many of the samples containing numerous young forms. It is hoped that these will be analysed and reported on in due course.

\section{DisCUSSION}

As far as I am aware this series of samples, collected by Mr Elmhirst for the study of the night migrant macrofauna of the intertidal waters throughout a whole year, is the first of the kind which has been made. The main purpose of the work is to show that this field is a fruitful one for further investigation. It is not proposed to discuss in detail the possible factors which underlie the migration of the species either individually or as a whole, but rather to indicate the problems requiring further investigation and to show how this series of samples demonstrates the positions at which the collection of further samples should be made. The samples were taken, in all cases, at the edge of inflowing or outflowing tide. Thus the position of each sample is determined by the position of the tide when the sample was taken, and they have served to show the general outline of the problems involved. The main point that emerges, apart from the fact that the major part of the night migrant population consists of Crustacea, is that the population falls into two well-marked groups: (a) that which normally lives in the intertidal sand of the bay and becomes migrant at night-time, and $(b)$ that which is carried in to the bay by the inflowing tide from other habitats. Thus, as an auxiliary study, it is necessary to know the fauna of the intertidal soil and also that of the adjacent deeper water habitats which may be (I) sand or mud habitats, or (2) algal habitats, or both. This investigation shows that both habitats contribute to the migrant population. To complete the analysis of the migrant fauna it is necessary to obtain samples of the microfauna, which in addition to the usual plankton organisms will consist of such forms as Harpacticids (Elmhirst, I935), and also to obtain a knowledge of the fishes which both as adults and 
in their young stages may migrate inshore at night-time in varying numbers at the different seasons of the year (Elmhirst, 1935; Marshall et al. 1939). By such studies it will eventually be possible to build up a picture of the extensive activities which occur in intertidal waters at night-time.

The data given in this paper and previously for Bathyporeia show that the sand population retains its zonation when migrant in the intertidal waters, but that species which are migrant from outside habitats are distributed over the whole tidal range and show no zonation. Thus, Pontocrates norvegicus and $P$. arenarius and the four species of Bathyporeia only occur in those samples taken over their immediate habitat, whilst Gammarus locusta occurs in practically every sample. The further investigation of the intertidal sand species involves three lines of sampling: (a) a series taken above the highwater mark of neap tides which will include as the main species Bathyporeia pilosa, (b) a series taken just below the mean sea level, i.e. a mid-tidal sample, which is the centre of abundance of Pontocrates norvegicus and Bathyporeia pelagica, and $(c)$ a series at the low-water mark of spring tides to include Bathyporeia elegans, Pontocrates arenarius, Pseudocuma cercaria and Cumopsis goodsiri as the dominant species. These three series of samples would also supply much information about the migrants from the deeper water habitats, but they would need supplementing by samples taken over their respective habitats to show whether the population differs at various points along the migratory path. Gammarus locusta is a suitable species in this respect. The sampling in deeper waters must include depth samples as well as surface samples; Pseudocuma, for instance, is known to remain associated with the water immediately over its habitat and not to rise in numbers to the surface.

Though the data here presented furnish evidence that the behaviour of the species changes at different times of the year, the apparent association of many species with varying lunar light intensities needs as continuous a series of samples as possible. Much further evidence is also required in regard to the time when the species rise, to show if it bears any relationship to the time of the rise of the moon and if it differs on moonlight or moonless nights. This factor may, however, be of considerably less significance than that of the degree of calmness or roughness of the tidal waters. It is probable that there is a close relationship between the calmness of the tidal waters and the degree of emergence of the species from their habitats. In view of all the factors involved, the collection of a perfect series of samples becomes almost an impossibility.

The results for the various species show that their behaviour does not follow any generalized form; but a broad distinction may be drawn, in the amphipods, between the intertidal sand-dwelling forms and the immigrant species. The migrant population in the former, typified by Pontocrates and Bathyporeia, shows all stages of maturity, whilst in the latter, typified by Gammarus and Nototropis, there is a predominance of young forms with the adults taking but little part in the migration. In the intertidal sand-dwelling 
forms adults tend to predominate over the young, with the adult males showing a stronger migratory tendency than the females. The reasons for this difference in behaviour can only be assumed. It may be imagined that the behaviour in both instances serves as a means of dispersal but with a difference in the age of the dispersal phase. It may be that the sand-living forms migrate to form pairs, while this may be possible amongst algal dwellers without the necessity of migration. A more detailed study of the relationship of the species to their habitat is needed, and of their reproductive habits. The latter are known for G. locusta from the work of Blegvad, and it is known that many sand-dwelling species feed whilst buried in the sand, and do not migrate for the purpose of obtaining food. In Eurydice, however, which is a day migrant as well as a night migrant, the movement is essentially a feeding one and the absence of egg-bearing females indicates that its main purpose is not that of reproduction.

The behaviour of the various species in regard to the lunar cycle shows that Pontocrates, Bathyporeia and Gammarus are similar; this suggests that a factor other than feeding and reproduction may be causative, and the difference in the time of appearance in the lunar cycle between the species of these genera and Pseudocuma suggests that the same factor may affect different species in different ways.

\section{SUMMARY}

The faunal analysis of forty-eight samples taken with a coarse tow-net across the intertidal waters of Kames Bay during 1936 shows that the night migrant crustacean population falls into two well-marked groups: (a) those species which live in the intertidal sand and perform simple vertical migrations at night-time into the intertidal waters, and $(b)$ those which are carried in by the tide into the intertidal area from various habitats which lie beyond the low-water mark of spring tides. In the former group the species of the genera Bathyporeia and Pontocrates are dominant and they retain their zonation as migrants, the population consisting of individuals in all stages of maturity. This is in sharp contrast to the latter group, typified by Gammarus locusta and Idotea viridis, which occur over the whole tidal range with a population in which the young immature stages are dominant. The Haustoriids Urothoë brevicornis and Haustorius arenarius occur as inhabitants of the sand, the former appearing occasionally in the tow-net samples and the latter absent from them. The Cirolanid Eurydice pulchra performs both day and night migration for the purposes of feeding.

Discussion of the results indicates the lines along which further investigations may be carried out. 


\section{REFERENCES}

Blegvad, H., 1922. On the biology of some Danish gammarids and mysids. Rept. Danish Biol. Station, Vol. xxvIII, pp. I-I03.

Dennell, R., I933. The habits and feeding mechanism of the amphipod Haustorius arenarius Slabber. Fourn. Linn. Soc. Zool. London, Vol. xxxviII, pp. 363-88.

Elmhirst, R., I93I. Studies on the Scottish marine fauna. The Crustacea of the sandy and muddy areas of the tidal zone. Proc. Roy. Soc. Edin., Vol. LI, pp. I6975.

1932. Quantitative studies between tide marks. Glasgow Naturalist, Vol. x, pp. 52-62.

I935. Inshore fish feeding ground. Ann. Rept. Scott. Mar. Biol. Assoc. I934-5, pp. 9-II.

FAGE, L., I933. Pêches planctoniques à la lumière effectuées à Banyuls-sur-Mer et à Concarneau. III. Crustacés. Arch. Zool. Expér. Gén., Vol. LXxvi, pp. ro5-248.

Foxon, G. E. H., 1936. Notes on the natural history of certain sand-dwelling Cumacea. Ann. Mag. Nat. Hist., Ser. Io, Vol. xvir, pp. 377-93.

Howes, N. H., I939. Observations on the biology and post-embryonic development of Idotea viridis (Slabber) from new England Creek south-east Essex. Fourn. Mar. Biol. Assoc., Vol. xxiII, pp. 279-310.

Marshall, S. M., Nicholls, A. G. \& ORR, A. P., I939. On the growth of young Herring in the Clyde. Fourn. Mar. Biol. Assoc., Vol. xxirI, pp. 427-55.

Patience, A., I909. On the genus Phoxocephalus. Glasgow Naturalist, Vol. I, pp. I. I634 .

RusSELl, F. S., I925. The vertical distribution of marine macroplankton. An observation on diurnal changes. Fourn. Mar. Biol. Assoc., Vol. xIII, pp. 769-809.

- I927. The vertical distribution of marine macroplankton. V. The distribution of animals caught in the ring-trawl in the daytime in the Plymouth area. Fourn. Mar. Biol. Assoc., Vol. xiv, pp. 557-608.

- I93I. The vertical distribution of marine macroplankton. XI. Further observations on diurnal changes. Fourn. Mar. Biol. Assoc., Vol. xvir, pp. 767-84. - 1934. The seasonal distribution of macroplankton as shown by catches in the 2 metre stramin ring-trawl in off-shore waters off Plymouth. Fourn. Mar. Biol. Assoc., Vol. xIX, pp. 73-81.

SARs, G. O., I89I. Crustacea of Norway. I. Amphipoda. Kristiana.

STEPHEN, A. C., 1928. Notes on the quantitative distribution of molluscs and polychaetes in certain intertidal areas on the Scottish coast. Proc. Roy. Phys. Soc., Vol. XXI, pp. 205-I6.

Tattersall, W. M., I9r3. Clare Island Survey. Amphipoda. Proc. Roy. Irish Acad., Vol. xxxi, pp. I-42.

WATkIn, E. E., I939. The pelagic phase in the life history of the amphipod genus Bathyporeia. Fourn. Mar. Biol. Assoc., Vol. xxin, pp. 467-8I. 